\title{
IMPLEMENTASI KURIKULUM 2013 PADA PEMBELAJARAN ILMU PENGETAHUAN ALAM (IPA) DI KELAS VI SEKOLAH DASAR NEGERI 150 TINABITE KABUPATEN BOMBANA
}

\author{
Sri Dayanti ${ }^{\bowtie}$, Junaidin ${ }^{2}$, Asrul $^{3}$ \\ Program Studi Administrasi Pendidikan, Universitas Muhammadiyah \\ Kendari ${ }^{123}$ \\ Email: srydayanti52@gmail.com
}

\begin{abstract}
ABSTRAK
Tujuan penelitian ini adalah untuk mengetahui Implementasi Kurikulum 2013 Pada Pembelajaran Ilmu Pengetahuan Alam (IPA) Di Kelas VI SD Negeri 150 Tinabite Kabupaten Bombana. Jenis penelitian yang digunakan untuk mengkaji implementasi kurikulum 2013 yang dilaksanakan oleh Sekolah Dasar Negeri 150 Tinabite Kabupaten Bombana adalah deskriptif-kualitatif. Adapun subjek dalam penelitian ini yaitu kepala sekolah, guru-guru dan siswa SD Negeri 150 Tinabite Kabupaten Bombana pada tahun ajaran 2019/2020 yang berjumlah 12 orang, yang terdiri dari Kepala Sekolah, 1 orang guru dan 10 orang siswa. Hasil penelitian ini menunjukan bahwa implementasi kurikulum 2013 pada mata pelajaran IPA Kelas VI SD Negeri 150 Tinabite Kabupaten Bombana yang diimplementasikan melalui (1) Implementasi perencanaan pembelajaran, guru sudah menyusun RPP secara mandiri yang dikembangkan dari silabus kurikulum 2013 dan berpedomam pada Permendikbud 81A serta rencana pelaksanaan pembelajaran yang disesuaikan dengan pengembangan kurikulum 2013, yaitu mengenai penyusunan RPP oleh guru yang merujuk pada silabus yang dibuat pemerintah. (2) Implementasi pelaksanaan pembelajaran guru sudah menerapkan pendekatan saintifik, dengan menfasilitasi dan mengembangkan karakter siswa, baik pembelajaran di kelas maupun di luar kelas melalui metode diskusi, kerja kelompok dan praktikum. (3) Implementasi penilaian sudah dilaksanakan oleh guru sesuai dengan prinsip- prinsip yang tertulis dalam Permendikbud No.66 Tahun 2013 tentang standar penilaian pendidikan yang meliputi penilaian kompetensi keterampilan, pengetahuan dan sikap yang dilakukansecara berimbang sehingga dapat digunakan untuk menentukan posisi relatif setiap siswa terhadap standar yang telah ditetapkan.
\end{abstract}

Kata Kunci: Implemetasi; Kurikulum 2013

\begin{abstract}
The purpose of this study was to determine the implementation of the 2013 Curriculum in Natural Science Learning (IPA) in Class VI of the 150 Tinabite Elementary School, Bombana Regency. The type of research used to examine the implementation of the 2013 curriculum carried out by the 150 Tinabite Elementary School, Bombana Regency is descriptivequalitative. The subjects in this study were the principal, teachers and students of the 150 Tinabite Elementary School, Bombana Regency in the academic year 2019/2020, totaling 12 people, consisting of the principal, 1 teacher and 10 students. The results of this study indicate that the implementation of the 2013 curriculum in science subjects Class VI SD Negeri 150 Tinabite, Bombana Regency which is implemented through (1) Implementation of learning planning, The teacher has independently compiled the RPP which was developed from the 2013 curriculum syllabus and is based on Permendikbud 81A as well as a learning implementation plan that is adjusted to the 2013 curriculum development,
\end{abstract}


namely regarding the preparation of RPP by the teacher referring to the syllabus made by the government. (2) The implementation of teacher learning has applied a scientific approach, by facilitating and developing student character, both learning in class and outside the classroom through discussion methods, group work and practicum. (3) The implementation of the assessment has been carried out by the teacher in accordance with the principles written in Permendikbud No.66 of 2013 concerning education assessment standards which include skills competency assessment, knowledge and attitudes are carried out in a balanced manner so that they can be used to determine the relative position of each student against the predetermined standards.

Keywords: Implementation; Curriculum 2013

\section{PENDAHULUAN}

Kurikulum merupakan salah satu komponen dalam pendidikan formal, maupun non formal yang harus dikonsep dan dilaksanakan serta dievaluasi, untuk merealisasikan hal tersebut, membutuhkan perangkat lunak maupun perangkat keras, sarana dan prasarana sebagai penyempurna dalam menuju suksesnya tujuan pendidikan Nasional dan Institusional. Kurikulum 2013 bertujuan untuk melahirkan generasi masa depan yang cerdas intelektualnya, cerdas emosinal, sosial, dan spiritualnya. Hal itu tampak dengan teritegrasikannya nilai-nilai karakter kedalam proses pembelajaran tidak lagi menjadi suplemen seperti Kurikulum 2006. Pendekatan dan strategi pembelajaran yang digunakan dengan memberikan ruang kepada peserta didik untuk mengkontruksi pengetahuan baru berdasarkan pengalaman belajar yang diperoleh dari kelas, lingkungan sekolah, dan masyarakat.

Kurikulum 2013 merupakan kurikulum baru yang mulai ditetapkan pada tahun ajaran 2013/2014. Pada kurikulum 2013 yang menjadi titik tekan pada kurikulum 2013 ini adalah keseimbangan dan penigkatan shoftskill dan hardskill yang meliputi aspek kompetensi-kompetensi sikap, keterampilan, dan pengetahuan. Kemudian, kedudukan kompetensi yang semula yang diturunkan dari mata pelajaran berubah menjadi mata pelajaran yang dikembangkan dari kompetensi, Fadilah (2014: 16). Kurikulum 2013 merupakan kurikulum yang berbasis pada pengembanagan kompetensi siswa. Kurikulum berbasis kompetensi (outcomes-based curriculum) yaitu pengembangan kurikulum yang diarahkan pada pencapaian kompetensi seperti yang telah dirumuskan dalam Standar Kompetensi Lulusan, Anang (2013: 1). Tujuan pengembangan Kurikulum 2013 berdasarkan Permendikbud No. 69 tahun 2013 Tentang Kerangka Dasar dan Struktur Kurikulum Sekolah Menengah Atas/Madrasah Aliyah) adalah mempersiapakan manusia Indonesia agar memiliki kemampuan hidup sebagai pribadi dan warga Negara yang beriman, produktif, kreatif, inovatif, dan afektif serta mampu berkontribusi pada kehidupan bermasyarakat, berbangsa, bernegara, dan peradaban dunia. Poerwari dan Amri (2013: 214-215) mengemukakan lima prinsip dalam pengembangan kurikulum, yaitu: (a) Prinsip relevansi, (b) Prinsip feksibilitas, (c) Prinsip kontinuitas, d) Prinsip efisiensi, dan e) Prinsip efektifitas. Mahmud (Hamid, 2012: 6), Kurikulum dikembangkan dengan memperhatikan keragaman karakteristik peserta didik, kondisi daerah, jenjang, serta jenis pendidikan,tanpa membedakan membedakan agama, suku, budaya dan adat istiadat, serta status sosial ekonomi dan gender. Kurikulum meliputi substasi komponen muatan wajib kurikulum,muatan local, dan pengembangan diri secara terpadu,serta disusun dalam keterkaitan dan kesinambungan yang bermakna dan tepat antar substansi.

Implementasi kurikulum 2013 merupakan aktualisasi kurikulum dalam pembelajaran dan pembentukan kompetensi serta karakter peserta didik. Hal tersebut menuntut keaktifan guru dalam menciptakan dan menumbuhkan berbagai kegiatan sesuai 
dengan rencana yang telah diprogramkan, Mulyasa (2013: 99). Selanjutnya bahwa pengembangan kurikulum dapat didefinisikan sebagai proses perencanaan pembelajaran, pelaksanaan pemebelajaran dan evaluasi pemebelajaran yang pada akhirnya mengahsilkan rencana kurikulum, Lunenburg (2011: 01). Adapun tahap-tahap dalam merencanakan pembelajaran yang berkualitas yaitu keahlian guru diharapkan mencerminkan kemampuan guru dalam menegelola proses belajar mengajar yang meliputi hal-hal sebagai berikut. 1) Kemampuan merencanakan proses belajat mengajar (a) Kemampuan merumuskan tujuan pengajaran. (b) Kemampuan memilih metode alternatif. (c) Kemmapuan memilih metode yang sesuai dengan tujuan pengajaran. (d) Kemampuan merencanakan langkah-langkah pengajaran. 2) Kemampuan mempersiapkan bahan pengajaran (a) Kemampuan menyiapkan bahan yang sesuai dengan tujuan. (b) Kemampuan mempersiapkan pengayaan bahan pengajaran. (c) Kemampuan bahan pengajaran. 3) Kemampuan merencanakan media dan sumber belajar. (a) Kemampuan memilih media pengajaran yang tepat. (b) Kemampuan memilih sumber pengajaran yang tepat. Sementara pelaksanaan proses belajar mengajar adalah proses berlangsungnya belajar mengajar di kelas yang merupakan inti dari kegiatan pendidikan disekolah, Suryosubroto (2006: 20).

Hasil penelitian yang dilakukan oleh Said Alfatih (2017), menunjukkan bahwa Madrasah Aliayah Indotec Kenadri telah menerapkan Kurikulum 2013 pada mata pelajaran PAI dengan cukup baik. Mulai dari perencanaan guru menyususun RPP berpedoman dan Pada saat proses evaluasi, guru juga sudah melakukan penilaian autentik yaitu dengan menilai sikap yang meliputi observasi, penilaian diri, penilaian teman sejawat. Selanjutnya hasil penelitian yang dilakukan oleh Kaharuddin $\mathrm{T}$ (2012), menunjukkan bahwa implementasi KTSP pada mata pelajaran PKn pada SMP Negeri 5 Sampara belum terlaksana dengan baik sesuai standar nasional pendidikan, pada aspek perencanaan pelaksanaan maupun penilaian. Hal ini disebabkan karena nilai KKM tidak berdasarkan kompleksitas, daya dukung dan kemampuan siswa belum menggunakan penilaian variasi dan tidak adanya instrumen baik kognitif maupun penilaian afektif.

Berdasarkan hasil observasi awal di SD Negeri 150 Tinabite Kabupaten Bombana, proses pembelajaran yang dilakukan oleh guru di kelas sudahmengimlementasikan Kurikulum 2013 tetapi masih terdapat kendala-kendala seperti buku untuk siswa yang belum terpenuhi dan juga guru yang belum terbiasa dengan pembelajaran tematik. Saat penulis menawarkan diri untuk melakukan penelitian tentang Implementasi Kurikulum 2013, Kepala sekolah dan guru-guru memberi respon yang positif, dan dalam pandangan serta pemahaman mereka, mereka mengungkapkan bahwa kegiatan penelitian ini sangat bermanfaat bagi Sekolah Dasar Negeri 150 Tinabite Kabupaten Bombana, Karena hasilnya dapat dijadikan masukan dan bahan pertimbangan bagi Sekolah untuk melakukan pembaharuan dan perbaikan dalam Implementasi Kurikulum 2103 kearah yang lebih baik. Dengan demikian tujuan dalam penelitian ini adalah untuk mendeskripsikan implementasi kurikulum 2013 pada pembelajaran ilmu pengetahuan alam (IPA) di kelas VI Sekolah Dasar Negeri 150 Tinabite Kabupaten Bombana.

\section{METODE PENELITIAN}

Jenis penelitian yang digunakan untuk mengkaji Implementasi Kurikulum 2013 yang dilaksanakan oleh Sekolah Dasar Negeri 150 Tinabite Kabupaten Bombana adalah deskriptif-kualitatif. Metode penelitian dengan pendekatan naturalistik digunakan penulis untuk meneliti sesuai kondisi obyek yang alamiah, dimana peneliti sendiri yang bertindak sebagai instrumen kunci untuk mengumpulkan data dengan mengamati proses implementasi kurikulum 2013 yang terjadi di Sekolah Dasar Negeri 150 Tinabite Kabupaten Bombana. Adapun subjek dalam penelitian ini yaitu kepala sekolah, guru-guru dan siswa 
Sekolah Dasar Negeri 150 Tinabite Kabupaten Bombana pada tahun ajaran 2019/2020 yang berjumlah 12 orang, yang terdiri dari Kepala Sekolah, 1 orang guru dan 10 orang siswa.

Sesuai dengan rumusan masalah dan tujuan yang diharapkan pada penelitian ini, maka yang menjadi fokus perhatian dan pengamatan, yang selanjutnya akan dikaji secara mendalam dalam hal ini adalah bagaimana Implementasi Kurikulum 2103 Sekolah Dasar Negeri 150 Tinabite Kabupaten Bombana, Aspek yang 49 dianalisis dan di amati adalah program perencanaan, kegiatan implementasi dan hasil implementasi yang dilakukan kepala sekolah, guru-guru dan siswa, teknik pengumpulan data yang diperlukan dalam penelitian ini yaitu, (1) observasi langsung (2) wawancara mendalam, dan (3) studi dokumentasi.

Teknik analisa data yang digunakan pada penelitian ini adalah teknik analisis deskriptif-kualitatif berdasarkan kenyataan yang diperoleh di lapangan. Sebagaimana yang dikemukakan oleh Miles dan Huberman (Sugiyono, 2011: 334) dimana komponen reduksi data dan sajian data dilakukan bersamaan dengan proses pengumpulan data. Setelah data terkumpul, maka keempat komponen analisis yaitu (pengumpulan data, reduksi data, sajian data dan penarikan kesimpulan) saling berinteraksi. Untuk mengecek keabsahan data dalam penelitian ini, peneliti menggunakan teknik Triangulasi data, triangulasi dalam pengujian credibilitas (kepercayaan) ini diartikan sebagai pengecekan data dari berbagai sumber dengan berbagai cara dan berbagai waktu .

\section{HASIL PENELITIAN DAN PEMBAHASAN}

\section{Perencanaan Pembelajaran Kurikulum 2013 Mata Pelajaran IPA Kelas VI SD Negeri 150 Tinabite Kabupaten Bombana}

Sebelum mempersiapkan penyusunan RPP, sekolah terlebih dahulu mengadakan musyawarah yang dilakukan dalam bentuk Kelompok Kerja Guru (KKG) dalam kegiatan tersebut guru dituntut agar dalam penyusunan RPP harus merujuk pada silabus yang sesuai dengan Satandar Nasional Pendidikan (SNP) atau sesuai dengan aturan dari Direktorat pendidikan dasar dan menengah, Dengan kriteria minimal tentang sistem pendidikan diseluruh indonesia

Perencanaan pembelajaran merupakan suatu proses mempersiapkan langkahlangkah yang akan dilaksanakan untuk mencapai tujuan yang telah ditetapkan dalam implemetasi kurikulum 2013 yang meliputi penyususnan materi pelajaran, penggunaan media pengajaran, penggunaan pendekatan dan metode pengajaran, dan evaluasi. Perencanaan pembelajaran kurikulum 2013 mata pelajaran IPA pada SD Negeri 150 Tinabite Kabupaten Bombana dalam menyususn RPP dilakukan secara bersama-sama melalui kelompok kerja guru (KKG) dan menyusun RPP berdasarkan silabus yang dibuat oleh Direktorat serta untuk memperkaya wawasan guru dalam pembelajaran maka dilakukan pelatihan di sekolah.

\section{Pelaksanaan Kurikulum 2013 Mata Pelajaran IPA Kelas VI SD Negeri 150 Tinabite Kabupaten Bombana}

Berdasarkan penelitian yang diperoleh dilapangan selama peneliti melakukan penelitian bahwa pelaksanaan pembelajaran yang dilakukan guru berpedoman pada Permendikbud No. 65 Tahun 2013 tentang standar proses pembelajaran dan Permendiknas No. 20 tentang satandar kompetensi dan lulusan pendidikan dasar dan menengah kurikulum 2013. Pembelajaran IPA di SD Negeri 150 Tinabite Kabupaten Bombana secara umum telah sesuai dengan RPP yang telah disusun Oleh Guru. Guru berusaha untuk melaksanakan pembelajaran sesuai dengan RPP agar pembelajaran berlangsung secara terorganisir. 
Pedoman pelaksanaan kurikulum 2013 pada pelaksaan pembelajaran yaitu mencakup kegiatan pendahuluan dimana guru menyiapakan fisik maupun psikis peserta didik, menjelaskan tujuan pembelajaran atau kompetensi dasar yang harus dicapai, dan menyampaikan cakupan garis besar cakupan materi yang hendak diajarkan. Selanjutnya kegiatan inti guru menggunakan metode yang sesuai dengan karakteristik peserta didik dan mata pelajaran yang meliputi proses observasi, menanya, mengumpulkan informasi, asosiasi, dan mengkomuniksikan. Selanjutnya kegiatan penutup dimana guru bersamasama dengan peserta didik membuat rangkuman atau simpulan pelajaran, melakukan evaluasi, atau refleksi terhadap kegiatan yang sudah dilaksanakan.

\section{Penilaian Pembelajaran Kurikulum 2013 Mata Pelajaran IPA Kelas VI SD Negeri 150 Tinabite Kabupaten Bombana}

Penilaian pembelajaran adalah proses pengumpulan informasi tentang hasil dari aktifitas belajar siswa dengan tujuan untuk mengetahui apa yang telah diimplementasikan dalam pemebelajaran sudah terlaksana dengan baik atau belum serta untuk mengetahaui sejauhmana implementsi tersebut berjalan, Terutama yang berhubungan dengan Implemetasi Kurikulum 2013. Penerapan kurikulum 2013 melalui langkah-langkah yang dimulai dari perencanaan pembelajaran, pelaksanaan pembelajaran, setelah itu melakukan evaluasi yang bertujuan untuk mengetahui keberhasilan siswa dalam menerima pelajaran maka guru melakukan evaluasi kepada siswa. Guru-guru di SD Negeri 150 Tinabite sealalu melakukan evaluasi untuk mengetahui apakah tujuan yang telah dirumuskan tercapai atau belum, dan apakah materi yang diajarkan sudah cukup tepat atau belum, untuk mengetahui semua itu dilakukan evaluasi atau penilaian, penilaian yang dilakukan oleh guru mencakup penilaian sikap, pengetahuan, dan keterampilan. Penilaian merupakan kegiatan penilaian terhadap pencapaian kompetensi bagi peserta didik. Mulyasa (2013: 69). Evaluasi adalah bertujuan untuk mengetahui apakah sesuatu yang diterapkan berjalan dengan baik atau tidak dan sejauh mana penerapan tersebut berjalan khususnya dalam penerapan dan pelaksanaan, pendekatan saintifik, media dan metode didalam kurikulum 2013.

Imlementasi kurikulum 2013 telah dilaksanakan sejak tahun pelajaran 2014/2015 sampai sekarang dan berjalan dengan baik sekolah memberikan pelatihan dalam Imlementasi pembelajaran dalam kurikulum 2013 sehingga dalam pelaksanaannya di SD Negeri 150 Tinabite Kabupaten Bombana dapat terlaksana dengan baik sesuai dengan pedoman pelaksanaan yang ditetapkan oleh pemerintah.

Permendikbud No. 81A Tahun 2013 tentang implementasi kurikulum menjelaskan bahwa pengembangan RPP dapat dilakukan oleh guru secara mandiri atau secara bersamasama melalui KKG di dalam suatu sekolah tertentu difasilitasi dan disupervisi kepala sekolah atau guru senior yang ditunjuk oleh kepala sekolah. Penyusunan RPP yang dilakukan secara musyawarah melalui tim KKG di sekolah membuat guru saling bertukar pikiran sehingga guru yang belum mengikuti pelatihan kurikulum 2013 memperoleh informasi dari guru yang telah mengikuti pelatihan. Pelatihan dan pendidikan (diklat) melalui In House Training yang diikuti guru di sekolah masing-masing memberikan tambahan pengetahuan dan pemahaman mengenai kurikulum 2013. Pelatihan tersebut memaparkan mengenai penyusunan RPP dan bagaimana melakukan proses pembelajaran menggunakan pendekatan saintifik sehingga guru memiliki bekal dan kemampuan dalam menyusun RPP kurikulum 2013 dan diharapkan dapat mengimplementasikannya dengan baik. Guru telah menyusun perencanaan pembelajaran berupa RPP dengan baik berdasarkan silabus yang dibuat oleh Direktorat. RPP yang disusun guru telah memenuhi sebagian besar indikator dalam Permendikbud No.65 Tahun 2013 tentang standar proses. RPP yang disusun guru telah memfasilitasi siswa untuk melakukan pembelajaran IPA dan yang lainnya dengan pendekatan saintifik yang merupakan penekanan dari kurikulum 
2013. Dengan demikian penulis dapat menyimpulkan bahwa sekolah tersebut sudah menyususun perencanaan kurikulum 2013 sesuai dengan silabus yang dibuat oleh Direktorat. Penyusunan perencanaan antara lain penyusunan RPP dengaan membuat sebuah tim atau dilakukan bersama-sama.

Pelaksanaan pembelajaran yang diteliti adalah kegiatan pembelajaran yang dilakukan guru dengan berpedoman pada Permendikbud No. 65 tahun 2013 tentang standar proses. Pembelajaran di SD Negeri 150 Tinabite Kabupaten Bombana secara umum telah sesuai dengan RPP yang telah disusun. Guru selalu berusaha membuat pembelajaran berlangsung sesuai RPP agar dapat mengetahui kekurangan dan kelebihan selama proses pembelajaran. Dengan berpedoman pada RPP, guru dapat mengajar secara sistematis, tanpa khawatir keluar dari tujuan, ruang lingkup materi, strategi pembelajaran, atau keluar dari sistem evaluasi yang seharusnya dilakukan. Perencanaan adalah kegiatan menyusun langkah-langkah yang akan dilaksnakan untuk mencapai tujuan yang telah ditentukan. Namun yang lebih utama adalah perencanaan yang dibuat harus dilaksanakan dengan mudah dan tepat sasaran, Majid (2009: 15). Dalam merencanakan kegiatan yang hendak dilaksanakan dalam hal ini pelaksanaan pembelajaran seorang guru harus mampu menyusun perencanaan yang mudah untuk direalisaikan perencanaan tersebut harus tepat sasaran sehingga dalam pelaksnaannya berjalan dengan baik sesuai dengan tujuan yang ingin dicapai. Berdasarkan hasil analisis pelaksanaan pembelajaran IPA dalam penerapan kurikulum 2013 di SD Negeri 150 Tinabite Kabupaten Bombana penulis menyimpulkan pada pelaksanaan pembelajaran guru berpedoman pada Permendikbud No.65 tahun 2013 tentang standar proses pembelajaran kurikulum 2013. Guru dalam melaksanakan pembelajaran dikelas telah sesuai dengan Rencana Pelaksanaan Pembelajaran (RPP) yang telah disusun sesuai dengan silabus dibuat oleh Direktorat.

\section{SIMPULAN}

Berdasarkan hasil penelitian dan pembahasan peneliti dapat menyimpulkan bahwa Imlementasi kurikulum 2013 mata pelajaran IPA di kelas VI SD Negeri 150 Tinabite Kabupaten Bombana sudah diimlementasi dengan baik. Yang dimulalai dari Perencanaan atau RPP sesuai dengan kurikulum 2013 dengaan berpedomam pada Permendikbud 81A. Rencana pelaksanaan pembelajaran yang disesuaikan dengan pengembangan Kurikulum 2013, yaitu mengenai penyusunan RPP oleh guru yang merujuk pada silabus yang dibuat pemerintah. Pelaksanaan pembelajaran yang disesuaikan dengan pengembangan Kurikulum 2013, yaitu mengenai pembelajaran siswa aktif, mandiri, kritis, pembelajaran berbasis pemecahan masalah, pola pembelajaran berbasis tim, penggunaan karakteristik pembelajaran yang disesuaikan dengan pendekatan saintifik. Evaluasi pembelajaran dalam penerapan kurikulum 2013 mata pelajaran sudah dilaksanakan oleh guru sesuai dengan prinsip-prinsip yang tertulis dalam Permendikbud No. 66 Tahun 2013 tentang standar penilaian pendidikan yang meliputi penilaian kompetensi keterampilan, pengetahuan dan sikap yang dilakukan secara berimbang.

\section{UCAPAN TERIMA KASIH}

Penulis menyampaikan ucapan terima kasih dan penghargaan kepada Bapak Junaidin, S.Pd., M.Pd selaku pembimbing I dan Bapak Asrul, S.Pd., M.Pd selaku pembimbing II.yang telah sabar, tekun, tulus dan ikhlas meluangkan waktu, tenaga dan pikiran memberikan bimbingan, motivasi, arahan, dan saran-saran yang sangat berharga kepada penulis selama menyusun hasil ini, dan seluruh civitas akademika Program Studi Administrasi Pendidikan, Fakultas Keguruan dan Ilmu Pendidikan, Universitas Muhammadiyah Kendari. 


\section{DAFTAR PUSTAKA}

Anang Tjahjono, 2013. Petunjuk Teknik Persiapan Implementasi Kurikulum Tahun 2013 Pada Minggu Pertama di Sekolah. Direktorat Jendral Pendidikan Menengah Kementrian Pendidikan dan Kebudayaan.

Fadillah, M. 2014. Implementasi Kurikulum 2013 dalam pembelajaran SD/MI/SMP/Mts.\& SMA/MA. Yogyakarta: AR-Ruzz Media

Hamid Darmadi, 2011. Metode penelitian Pendidikan. Bandung: alfabeta

Kaharuddin T. 2012.Tesis: Dengan Judul Implementasi Kurikulum Tingkat Satuan Pendidikan (KTSP) Pada Pembelajaran Pendidikan Kewarga Negaraan (Studi Deskriptif di SMP Negeri 5 Sampara Kecamatan Sampara Kabupaten Konawe).

Lunenburg FC. 2011. Curriculum Development: Inductive Models. Schooling 2.

Majid Abdul, 2009. Perencanaan Pembelajaran. Bandung: PT Remaja Rosdakarya.

Mulyasa, E. 2013. Pengembangan dan Implementasi Kurikulum 2013. Jakarta: PT. Remaja Rosdakarya.

Menteri Pendidikan dan Kebudayaan, 2013. Peraturan Menteri Pendidikan dan Kebudayaan No 81A tahun 2013 Tentang Implementasi Kurikulum 2013.

Permendikbud No. 69 tahun 2013 Tentang Kerangka Dasar dan Struktur Kurikulum Sekolah Menengah Atas/Madrasah Aliyah.

Poerwati, Loeloek Endah, dan Amri, Sofan, 2013. Panduan Memahami kurikulum 2013 Sebuah Inovasi Struktur kurikulum Penunjang Pendidikan Masa Depan. Jakarta: Pustaka Publisher.

Said Alfatih. 2017. Skripsi: Dengan Judul Implementasi Kurikulum 2013 Pada Mata Pelajaran Pendidikan Agama Islam di Madrasah Aliayah Indotec Kendari.

Sugiono. 2011. Metode Penelitian Kombinasi (Mixed Method), Bandung: Alfabeta.

Suryosubroto. B. 2005. Tatatlaksana Kurikulum. Jakarta: Rineka Cipta. 